\title{
Expression Analysis of Toll-Like Receptor2 in Bubaline Peripheral Blood Mononuclear Cells upon Stimulation by Bacillus Subtilis Cell Wall Peptidoglycan
}

\author{
${ }^{1}$ Syed Mohmad Shah * and ${ }^{2}$ Gandham Ravi Kumar \\ ${ }^{1}$ Animal Biotechnology Center, National Dairy Research Institute, Karnal, Haryana-132001. \\ ${ }^{2}$ Division of Veterinary Biotechnology, Indian Veterinary Research Institute, Bareilly- 243122.
}

\begin{abstract}
The study was conducted to analyze the effect of bacterial cell wall peptidoglycan on the induction of toll-like receptor 2 in peripheral blood mononuclear cells (PBMCs). The cultures were stimulated with $B$. subtilis cell wall peptidoglycan (sPGN) at final doses of 10,20,30,40 and $50 \mu \mathrm{g} / \mathrm{ml}$ and incubated for $3 \mathrm{~h}, 12 \mathrm{~h}$, $24 \mathrm{~h}$ and $36 \mathrm{~h}$ time periods, for all the treatments. We observed that sPGN not only activates TLR2 expression in PBMCs, in a dose-and-time dependent manner, but also induces tolerance to further expression, beyond a certain concentration of the antigen, irrespective of the incubation interval. In our study, PBMCs became refractory to further stimulation by sPGN beyond $30 \mu \mathrm{g} / \mathrm{ml}$ dose across all the incubation intervals, ranging from $3 h$ to $36 h$. The highest TLR2 induction across all doses of the antigen was observed at $24 h$ incubation interval, suggesting probably the optimum physiological response to the antigen. We also cloned and sequenced TLR2 expressed sequence tag from buffalo PBMCs and submitted the sequence to GenBank.
\end{abstract}

Keywords: Buffalo, Peripheral blood mononuclear cells, peptidoglycan, TLR2, tolerance.

\section{Introduction}

Toll like receptors (TLRs) constitute the essential components of innate immune system. They function by recognizing the microbial products termed as pathogen associated molecular patterns (PAMPs). This recognition leads to activation of innate immune system which in turn activates and further tailors the stronger and more specific adaptive immune system. The mammalian TLR multi-gene family consists of 11 members, of which TLR1-9 show conservation between humans and mice. The complete set of TLRs recognizes a broad variety of microorganisms from bacteria, fungi, viruses and even protozoa. The studies on TLR ligand recognition and further immune system tailoring has received a considerable attention for their implications to be used as vaccine adjuvants for generation of a better and directed immune responses ${ }^{1}$. The signaling pathway via TLR family is highly homologous to that via the IL-1 receptor family. TLRs interact with adaptor protein MyD88, which recruits IRAK. The association of activated IRAK with TRAF6, leads to the activation of several distinct signaling pathways, including MAPKs and NF-kB ${ }^{2}$. However, the induction of tolerance to further TLR activation has also been reported, and that too by the same ligands responsible for initial induction, nevertheless, the detailed molecular mechanisms of tolerance remain still elusive. For example, circulating lymphocytes from septic patients show reduced capacity to produce cytokines as compared to those from healthy controls, a phenomenon dubbed as, "endotoxin tolerance" ${ }^{3}$. Monocytes from septic patients also show reduced capacity to release TNF- $\alpha$, IL-1 $\beta$, IL-6, IL-10, and IL-12 ${ }^{4,5,6}$. Among the known TLRs, TLR2 is primarily implicated in recognition of Gram positive cell wall components, especially peptidoglycan (PGN) which activates immune system cells through TLR2 induced activation of NF-kB, that in turn regulates the expression of various genes involved in cytokine production ${ }^{7}$. TLR2 has received an extra attention due to contrasting reports about its ligand specificity and thereby downstream cytokine tailoring and the consequent immune response ${ }^{8,9}$. In this context, the present study was conducted to examine the effects on TLR2 induction in buffalo peripheral mononuclear cells (PBMCs) upon stimulation by Bacillus subtilis cell-wall peptidoglycan in a dose-and timedependent manner.

\section{Materials and methods}

\section{PBMC isolation, recovery and viability}

Blood samples were collected from six healthy and immune-competent Murrah buffalo heifers, aged two and a half years, maintained at Dairy farm, GADVASU, Ludhiana. Fifteen $\mathrm{ml}$ of blood per heifer was collected in $0.5 \mathrm{M}$ EDTA aseptically and stored at $4{ }^{\circ} \mathrm{C}$. The blood samples were processed within two hours for peripheral blood mononuclear cell (PBMCs) isolation by density gradient centrifugation, using Histopaque 1077 (Sigma, USA). Briefly, five $\mathrm{ml}$ of the collected blood sample was diluted in equal volume of phosphate buffered saline (PBS, pH 7.4) and layered over onto the equal volume of Histopaque 1077 (Sigma, USA), followed by centrifugation at $400 \mathrm{~g}$ for $25 \mathrm{~min}$, break off, at room temperature. The buffy layer, containing mononuclear 


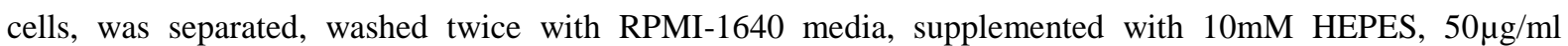
Gentamicin, $100 \mathrm{IU} / \mathrm{ml}$ of Penicillin, $100 \mu \mathrm{g} / \mathrm{ml}$ Streptomycin and $0.25 \mu \mathrm{g} / \mathrm{ml}$ Amphotericin, and sedimented to a pellet at $200 \mathrm{~g}$ for $10 \mathrm{~min}$. The recovery and viability of the isolated PBMCs was determined by haemocytometer counting, using trypan blue dye exclusion method. For this, $10 \mu 1$ of the cell suspension was mixed with $10 \mu \mathrm{l}$ of $0.4 \%$ trypan blue and incubated for 3 to $5 \mathrm{~min}$ at room temperature. $10 \mu \mathrm{l}$ of this mixture was injected beneath the cover slip on a haemacytometer. The unstained (viable) and stained (dead) cells were counted from the central large squares of haemacytometer. The total number of viable cells counted on an average was $2.4 \times 10^{6} / \mathrm{ml}$, accounting for $91 \%$ viability.

\section{Total RNA Isolation}

The total RNA was isolated from PBMCs using Tri reagent (MRC, Inc) following the manufacturer's instructions. Isolated RNA was treated with RNase-Free DNase 1 (Qiagen) for $90 \mathrm{~min}$ at room temperature to ensure DNA removal. The concentration and purity of recovered RNA was measured on nano drop (Thermo scientific). The quality of RNA was acceptable if the ratio of optical density at $260 \mathrm{~nm}$ to that at $280 \mathrm{~nm}$ was $>1.9$. The quality of RNA was checked on Experion automatic capillary electrophorosis system (Bio Rad) (Figure 1).

\section{Reverse Transcriptase- Polymerase Chain Reaction}

The extracted RNA was reverse transcribed using the First strand cDNA synthesis kit (Fermentas Life sciences) according to manufacturer's instructions. Briefly, oligo dT primer $(0.5 \mathrm{mg})$ was used to reverse transcribe $2 \mu \mathrm{g}$ of RNA in the presence of dNTP's $(250 \mathrm{mM})$, reverse transcriptase buffer $(10 \mathrm{mMTris}-\mathrm{HCl}, 50$ $\mathrm{mMKCl}, 0.1 \%$ TritonR-X-100), M-MuLV Reverse transcriptase (20U), transcriptase buffer (250mM Tris-Hcl, $250 \mathrm{mM} \mathrm{Kcl}, 20 \mathrm{mM} \mathrm{MgCl}_{2}, 50 \mathrm{~mm}$ DTT) and Riboblock RNase Inhibitor (20 units) at $37^{\circ} \mathrm{C}$ for $60 \mathrm{~min}$ followed by termination of the reaction at $70^{\circ} \mathrm{C}$.

The primer sequences, 5'-AGATTCATGATAAGGATTC3'(Forward) and 5'TCAACAACTTATTTCTGGAAA3'(Reverse) were designed from cattle TLR2 sequence (Genbank Acession No.EU005236) to amplify a 981bps TLR2 buffalo gene fragment. The amplification was carried out in 50 1 final volume containing $1.5 \mathrm{mM} \mathrm{MgCl}_{2}, 50 \mathrm{mM}$ Tris- $\mathrm{HCl}\left(\mathrm{pH} 9.0\right.$ at $\left.25^{\circ} \mathrm{C}\right), 15 \mathrm{mM}(\mathrm{NH} 4) 2 \mathrm{SO} 4$ and $0.1 \%$ Triton$\mathrm{X} ; 0.4 \mu \mathrm{M}$ of primers; $200 \mu \mathrm{M}$ of each dNTP's and 1 unit of Pfu Taq Polymerase. After a denaturation at $94^{\circ} \mathrm{C}$ for 5 minutes, 35 cycles of amplification were performed as follows: denaturation at $94^{\circ} \mathrm{C}$ for $45 \mathrm{sec}$, annealing at $64^{\circ} \mathrm{C}$ for $1 \mathrm{~min}$ and extension at $72^{\circ} \mathrm{C}$ for $30 \mathrm{sec}$. A final extension step of $10 \mathrm{~min}$ at $72^{\circ} \mathrm{C}$ ended the reaction. PCR product was resolved in a $1 \%$ agarose gel. The PCR amplicon was recovered from low melting point agarose purified, cloned into the pGEMT vector (Promega, Madison, USA) (Figure 2) and sequenced using automated dye-terminator cycle sequencing method with Ampli Taq DNA polymerase in ABI PRIZM 377 DNA sequencer (Perkin-Elmer). The fragment was sequenced at least twice with each primer to reduce possibility of sequencing artifacts. The sequence obtained was submitted to GenBank under accession number FR877561.

\section{PBMC culture and stimulation}

$500 \mu \mathrm{l}$ of the isolated PBMC suspension per $\mathrm{ml}$ of the culture volume $\left(2.4 \times 10^{6}\right.$ viable cells $\left./ \mathrm{ml}\right)$, was cultured in RPMI-1640 medium supplemented with HEPES Buffer $(10 \mathrm{mM})$, L-glutamine $(2 \mathrm{mM})$, Gentamicin $(50 \mu \mathrm{g} / \mathrm{ml})$, Pencillin $(100 \mathrm{IU} / \mathrm{ml})$, Streptomycin $(100 \mu \mathrm{g} / \mathrm{ml})$ and Amphotericin B $(0.25 \mu \mathrm{g} / \mathrm{ml})$ and stimulated with peptidoglycan (sPGN) of Bacillus subtilis cell wall origin (Sigma Life sciences, USA) in a dose- and timedependent manner. The working concentration of the soluble petidoglycan (sPGN), prepared in sterile tissue culture grade endotoxin free water, was $1 \mu \mathrm{g} / \mu \mathrm{l}$. The cultures in 6-well tissue culture plates were stimulated with $10,20,30,40$ and $50 \mu \mathrm{g} / \mathrm{ml}$ final dose of sPGN. A non-stimulated culture plate acted as the control. The cultures were incubated at $37^{\circ} \mathrm{C}$ and $5 \% \mathrm{CO}_{2}$ under humidified conditions for $3 \mathrm{~h}, 12 \mathrm{~h}, 24 \mathrm{~h}$ and $36 \mathrm{~h}$ time periods with media changes every $12 \mathrm{~h}$. All the culture wells were microscopically examined at appropriate intervals to rule out bacterial and fungal contamination.

\section{MRNA quantification for TLR2}

Quantitative real-time PCR was performed using 7500 RT-PCR instrument (ABS) to study the relative gene expression of TLR2 across SPGN doses at the different incubation intervals using gene-specific primerprobe combinations (Sigma-Aldrich,USA) by Taqman chemistry. The software package, Primer Express version 3.0, was used to identify appropriate TaqMan primer- probe set, synthesized against its EST, sequenced earlier in the lab (Genbank accession No.EU005236). The sequence of the forward, reverse and probe were as: (Forward); 5'CTGGCCCTTCCTTCAAACC3' and reverse 5'TCCCGTTTTTTCTAGTGATTTCAAA3' and Probe[6FAM]TGGTTTTAAGGCAGAATC[BHQ1], respectively. The optimized qRT-PCR reaction contained $100 \mathrm{ng}$ of cDNA, $900 \mathrm{nM}$ of each of the primer and $200 \mathrm{nM}$ of the probe in a final volume of $20 \mu \mathrm{l}$. The reactions were run in triplicate using GAPDH as an endogenous control. The thermal cycling parameters, $50^{\circ} \mathrm{C}$ for $2 \mathrm{~min}$ 
for AmpErase UNG activation, $95^{\circ} \mathrm{C}$ for 10 min for AmpliTaq Gold DNA Pol. activation and 40 cycles of each $95^{\circ} \mathrm{C}$ for $15 \mathrm{~s}$ for denaturation/melting and $60^{\circ} \mathrm{C}$ for $1 \mathrm{~min}$ for annealing and extension, yielded optimum amplification. For the test genes and endogenous control standards 10 -fold serial dilutions were run in the study to estimate the efficiency of PCR and the percentage efficiency ranged between 90 to $100 \%$. The relative expression of TLR2 for each treatment was calculated using the $2-{ }^{\Delta \Delta} \mathrm{CT}$ method ${ }^{10}$. Results were analyzed and shown as fold change (log10 relative quantification) relative to the control group.

\section{Statistical analysis}

Analysis of variance with Dunett's test was used to compare the different groups with the control (JMP 8.0). The data are mean triplicate of the three experiments. Differences were considered significant at $\mathrm{p}<0.05$.

\section{Results}

At $3 \mathrm{~h}$ incubation, the expression of TLR2 was found to be greater than that of the unstimulated control, at all the concentrations of sPGN. The expression initially appeared to follow a dose-dependence pattern, but decreased after $30 \mu \mathrm{g} / \mathrm{ml}$ dose of the antigen. The expression, though decreased, remained consistent at $40 \mu \mathrm{g} / \mathrm{ml}$ and $50 \mu \mathrm{g} / \mathrm{ml}$ doses (Figure 3). The expression of TLR2 followed the same pattern at 24h incubation interval, albeit, the expression was higher as compared to that at $3 \mathrm{~h}$ time interval, for the respective sPGN doses. At $12 \mathrm{~h}$ incubation, the highest expression of TLR2 was again observed at $30 \mu \mathrm{g} / \mathrm{ml}$ dose, ascribing some implications to this concentration of the antigen. At $24 \mathrm{~h}$ incubation period, the expression of TLR2 was higher for the respective doses of sPGN in comparison to both at $3 \mathrm{~h}$ and $12 \mathrm{~h}$ incubations. Again, the induction was observed to be highest at $30 \mu \mathrm{g} / \mathrm{ml}$ dose of the stimulant. The expression of TLR2 was almost similar at 30 $\mu \mathrm{g} / \mathrm{ml}$ and $40 \mu \mathrm{g} / \mathrm{ml}$ antigenic dose, while it was significantly lower at $50 \mu \mathrm{g} / \mathrm{ml}$ concentration of the antigen. However, at $50 \mu \mathrm{g} / \mathrm{ml}$ dose, the TLR2 expression was greater than that observed at $20 \mu \mathrm{g} / \mathrm{ml}$ antigenic dose (Figure 3). The induction of TLR 2 at $36 \mathrm{~h}$ interval was akin to that at $24 \mathrm{~h}$ interval. At $10 \mu \mathrm{g} / \mathrm{ml}$ dose, the expression of TLR2 was highest when compared to the other incubation intervals, under study (Figure 3). But at other concentrations, viz., $20 \mu \mathrm{g} / \mathrm{ml}, 30 \mu \mathrm{g} / \mathrm{ml}, 40 \mu \mathrm{g} / \mathrm{ml}$ and $50 \mu \mathrm{g} / \mathrm{ml}$ it was significantly lower than that observed at $24 \mathrm{~h}$ incubation interval, but higher than what was observed at $3 \mathrm{~h}$ and $12 \mathrm{~h}$ time periods. The highest expression of TLR 2 at $36 \mathrm{~h}$ interval was again observed at $30 \mu \mathrm{g} / \mathrm{ml}$ dose of sPGN. From this study, it became apparent that sPGN induces TLR2 expression, appreciably in a dose-and time-dependent manner, but the PBMCs become refractory to the concentration of the antigen, beyond $30 \mu \mathrm{g} / \mathrm{ml}$. The increased expression of TLR2 at all concentrations of sPGN at $24 \mathrm{~h}$ interval when compared to other incubations might be suggestive of the optimum physiological response to the antigen. At $24 \mathrm{~h}$ incubation, the effect of sPGN induced tolerance to TLR2 expression was to some extent overcome, as indicated by the same levels of TLR 2 expression at 30 $\mu \mathrm{g} / \mathrm{ml}$ and $40 \mu \mathrm{g} / \mathrm{ml}$ antigenic doses.

\section{Discussion}

The relative increase in TLR2 expression at all doses of sPGN, as compared to the untreated control, is due to induction caused by sPGN stimulation which functions as the ligand for TLR2 and activates its transcription [11]. The expression is further up regulated by autocrine cytokines, viz., IL-10 and TNF- $\alpha$ which are produced by the stimulated PBMCs ${ }^{12}$. The time-dependent increase in the expression of TLR2 might be due to the time-lag between the antigen-receptor binding and the subsequent downstream signaling of TLR2 induction. We observed that the optimum induction occurred at $24 \mathrm{~h}$ time interval, as indicated by the highest level of mRNA transcripts of TLR2 at this incubation interval for all the corresponding antigenic doses. This might be suggestive of the time period required for optimum physiological response to activate the innate immune branch of the immune system against the antigen, under study. Furthermore, an increased expression of TLR2 in dose-dependent manner, as observed in our study, across all incubation intervals indicates, probably, the increased surface expression of TLR2 with the antigenic doses. Since, the difference in the relative expression of TLR2 was much higher between $3 \mathrm{~h}$ and $24 \mathrm{~h}$ time intervals than between $3 \mathrm{~h}$ and $12 \mathrm{~h}$ time intervals, it appears that the surface expression of TLR2 occurs after a minimum time lag of greater than $12 \mathrm{~h}$. Nakayama et.al $(2004)^{3}$ also concluded that the surface expression levels of TLR2 expression were not affected by peptidoglycan stimulation up to $16 \mathrm{~h}$ between cells treated with low and high levels of the antigen. The expression, however, increased up to a certain limit of antigenic dose $(30 \mu \mathrm{g} / \mathrm{ml})$ beyond which it either remained consistent or decreased. This might be due to sPGN induced tolerance to further induction. The tolerance might be due to change in the pattern of cytokines both Th1 and Th2 type, which are induced by TLR2 expression, as the manifestation of the immune response to the antigen. The tolerance to further TLR 2 induction might affect the expression and/or function of the intracellular intermediates downstream to TLR2. The similar conclusions were drawn by Medvedev et.al. $(2002)^{13}$ while observing disregulation of LPS-induced TLR4MyD88 complex formation and IL-1 receptor-associated kinase 1 activation in endotoxin tolerant human monocytes. The interception of recruitment of IRAK-1 to the TLR2/MyD88 complex has also been ascribed to be an important molecular mechanism of PGN-induced tolerance ${ }^{3}$. The reasons for the peptidoglycan tolerance 
which was not observed at $40 \mu \mathrm{g} / \mathrm{ml} \mathrm{sPGN}$ dose during $24 \mathrm{~h}$ time interval might be due to more increased expression of TNF- $\alpha$, at this incubation interval, which functions as an up regulator of TLR2 expression ${ }^{12}$.

\section{References}

[1]. Hirschfeld M, Weis J, Toshchakov V, Salkowski C, Cody M, Ward D, Qureshi N, Michalek S and Vogel S, Signaling by toll-like receptor 2 and 4 agonists results in differential gene expression in murine macrophages. Infect. Immun. 237 (2001) $1477-1482$.

[2]. Lemaitre,B, Nicolas E, Michaut L, Reichhart J and Hoffmann J, The dorsoventral regulatory gene cassette spätzle/Toll/cactus controls the potent antifungal response in Drosophila adults. Cell 86 (1996) 973-983.

[3]. Nakayama K., Shu O, Shintaro T, KunihisaT, Miki K, Satoshi K, Koichi H, Yohtaroh T and Yasuo O, Involvement of IRAK-M in Peptidoglycan-induced Tolerance in Macrophages. The Journal of Biological Chemistry 279 (2004) 6629-6634.

[4]. Munoz C, Carlet J, Fitting C, Misset B, Bleriot J and Cavaillon J, Dysregulation of in vitro cytokine production by monocytes during sepsis. Clin. Investig. 88 (1991) 1747-1754.

[5]. 5. Van Deuren, M, Van der Ven-Jongekrijg J, Demacker P, Bartelink A, Van K, Dalen R, Sauerwein R, Gallati H, Vannice J, and Van der Meer J, Differential expression of proinflammatory cytokines and their inhibitors during the course of meningococcal infections. J. Infect. Dis. 169 (1994) 157-161.

[6]. Ertel W, Kremer J, Kenney J, Steckholzer U, Jarrar D, Trentz O,and Schildberg, F, Downregulation of proinflammatory cytokine release in whole blood from septic patients. Blood 85 (1995) 1341-1347.

[7]. Wang J, Jorgensen E, Ellingsen M, Almiof C, Thiemermann J, Foster O, Aasen, and Solberg R, Peptidoglycan primes for LPSinduced release of proinflammatory cytokines in whole human blood. Shock 16 ( 2001) 178-182.

[8]. Travassos L,Girardin D, Philpott D, Blanot M, Nahori M, Werts C and Boneca I, Toll-like receptor 2-dependent bacterial sensing does not occur via peptidoglycan recognition. EMBO Rep. 5 (2004) 1000-1006.

[9]. Dziarski R and Gupta D, Staphylococcus aureus peptidoglycan is a toll-like receptor 2 activator: A re-evaluation. Infect. Immun. 73 (2005) 5212-5216.

[10]. Schmittgen T and Livak K. Analyzing real-time PCR data by the comparative C(T) method. Nat. Protoc. 3 (2008) 1101-1108.

[11]. Takeda K and Akira S, Toll-like receptors in innate immunity. Int. Immunology. 17 (2005) 1-14.

[12]. Zarember, $\mathrm{K}$ and Godowski P, Tissue expression of human Toll-like receptors and differential regulation of Toll-like receptor mRNAs in leukocytes in response to microbes, their products, and cytokines. J. Immunol. 168 (2002) 554-561.

[13]. Medvedev A, Lentschat A, Wahl L, Golenbock D, and Vogel S, Dysregulation of LPS-induced Toll-like receptor 4-MyD88 complex formation and IL-1 receptor-associated kinase 1 activation in endotoxin-tolerant cells. J. Immunol. 169 (2002) 5209-5216.

\section{Figure captions}

Figure 1: Experion Capillary Electrophoresis Graph of Total RNA extracted from PBMCs.

Figure 2: PCR amplicon of TLR2 EST clone.1,2,3- Plasmid Clones; 4- Negative Control; M-100kb Plus DNA ladder.

Fig.3: qRT-PCR expression of TLR2 after stimulation with B. Subtilis sPGN in a dose-and-time-dependent manner. Results shown as fold change ( $\log _{10}$ relative quantification (RQ)) relative to the control group. The data are the mean and SEM. $* \mathrm{P}<0.05$

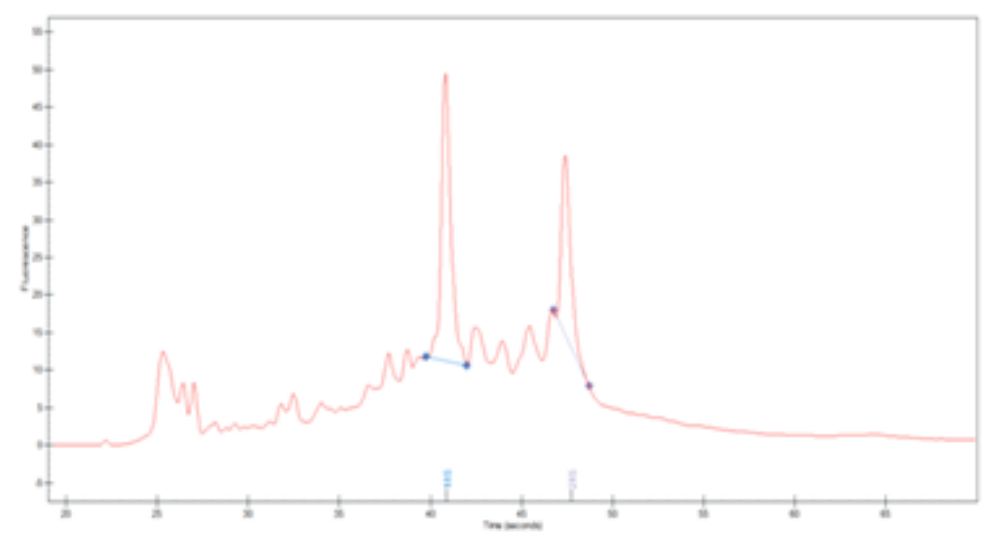




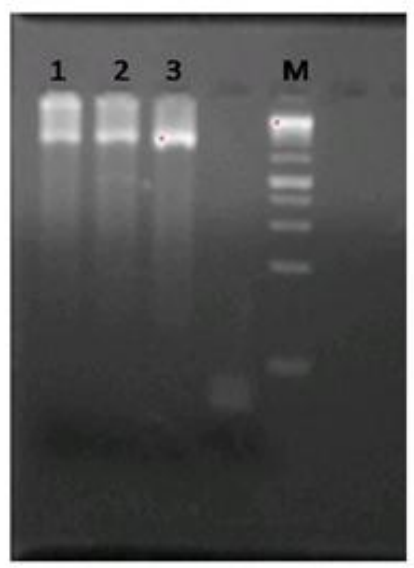

Fig. 2: PCR amplicon of TLR2 EST clone

$$
\begin{array}{ll}
\mathbf{1}, 2,3 & : \text { Plasmid samples } \\
\mathbf{4} & \text { : Negative Control } \\
\text { M } & : 100 k b \text { Plus DNA ladder }
\end{array}
$$

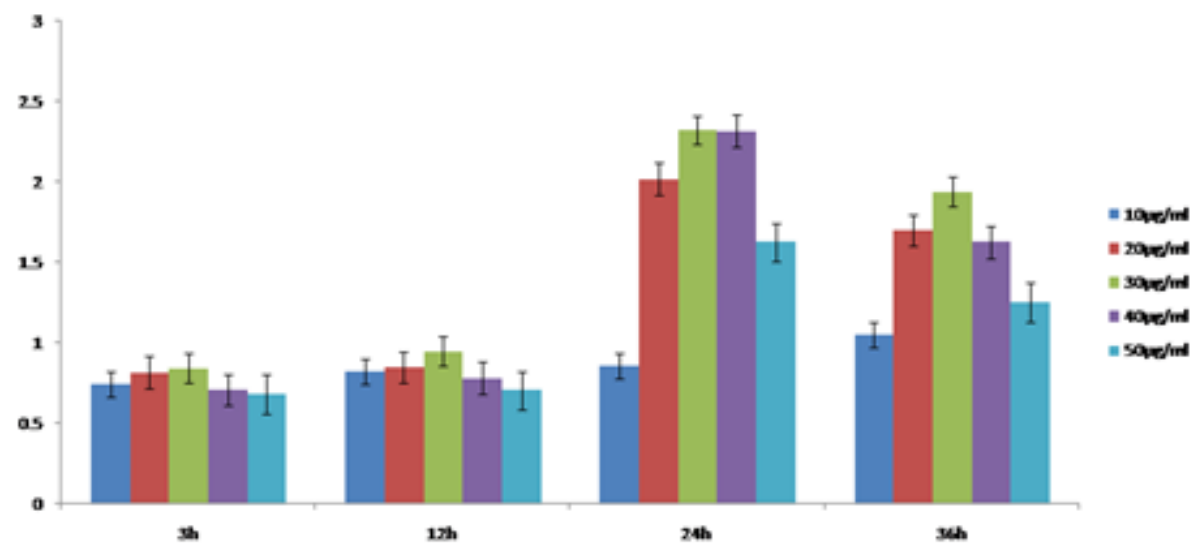

Fig.3:qRT-PCR expression of TLR2 after stimulation with B. Subtilis sPGN in a dose-andtime-dependent manner. Results shown as fold change (log 10 relative quantification (RQ))relative to the control group. The data are the mean and SEM. ${ }^{*} \mathrm{P}<0.05$ 